\title{
China's structural adjustment from the income distribution perspective
}

\author{
Chong-En Bai
}

\section{Correspondence:}

baichn@sem.tsinghua.edu.cn

School of Economics and

Management, Tsinghua University,

Beijing 100084, China

\section{Springer}

\begin{abstract}
This paper analyzes whether China's investment and savings rates are too high by considering the rate of return to investment and other factors. It also investigates the reasons for the rapid increase in the savings rate by using various sources of data and analytical tools. In particular, much attention is paid to the distribution of income among households, corporations, and the government, and to the labor income share. Policy proposals for structural adjustment are discussed based on the finding of the investigation.
\end{abstract}

Keywords: Structural imbalance; Savings rate; Investment rate; Household disposable income; The labor income share

\section{Background}

Since the start of the new century, China's economic demand structure has undergone a very rapid change. Household consumption as a share of GDP declined from $46.4 \%$ in 2000 to $33.8 \%$ in 2010; national savings rate increased from 37.7 to $52.6 \%$ in the same period. More detailed information about the demand structure of the economy is provided in Fig. 1.

This rapid change in the economic structure invites several important questions. The first is whether this structure is appropriate. The facts that China's savings rate rises very fast and that it is one of the very highest in the world do not necessarily mean it is too high. One reason is that China is still a relatively poor country with per capita capital stock much lower than that in advanced economies and therefore there is tremendous room for additional investment. Another reason is that other countries may be saving too little for the good of their economy. One needs to go beyond simple time series or cross-sectional comparison to answer the question.

The second question is, if one comes to the conclusion that China does save too much, what are the reasons behind the high savings rate? There are many possible answers to this question. One often mentioned reason is that people engage in a lot of precautionary savings in response to high level of risks that are not covered by insurance. These risks include that in post retirement income and expenses, in medical expenses, and in unemployment. Another often mentioned reason is that the costs of housing and education are very high and there are constraints on people's ability to borrow to spread out the payment for the costs, and consequently people save to pay for these costs. A third reason is that with rapid increase in income, people's

(c) 2015 Bai. Open Access This article is distributed under the terms of the Creative Commons Attribution 4.0 International License (http://creativecommons.org/licenses/by/4.0/), which permits unrestricted use, distribution, and reproduction in any medium, provided you give appropriate credit to the original author(s) and the source, provide a link to the Creative Commons license, and indicate if changes were made. 


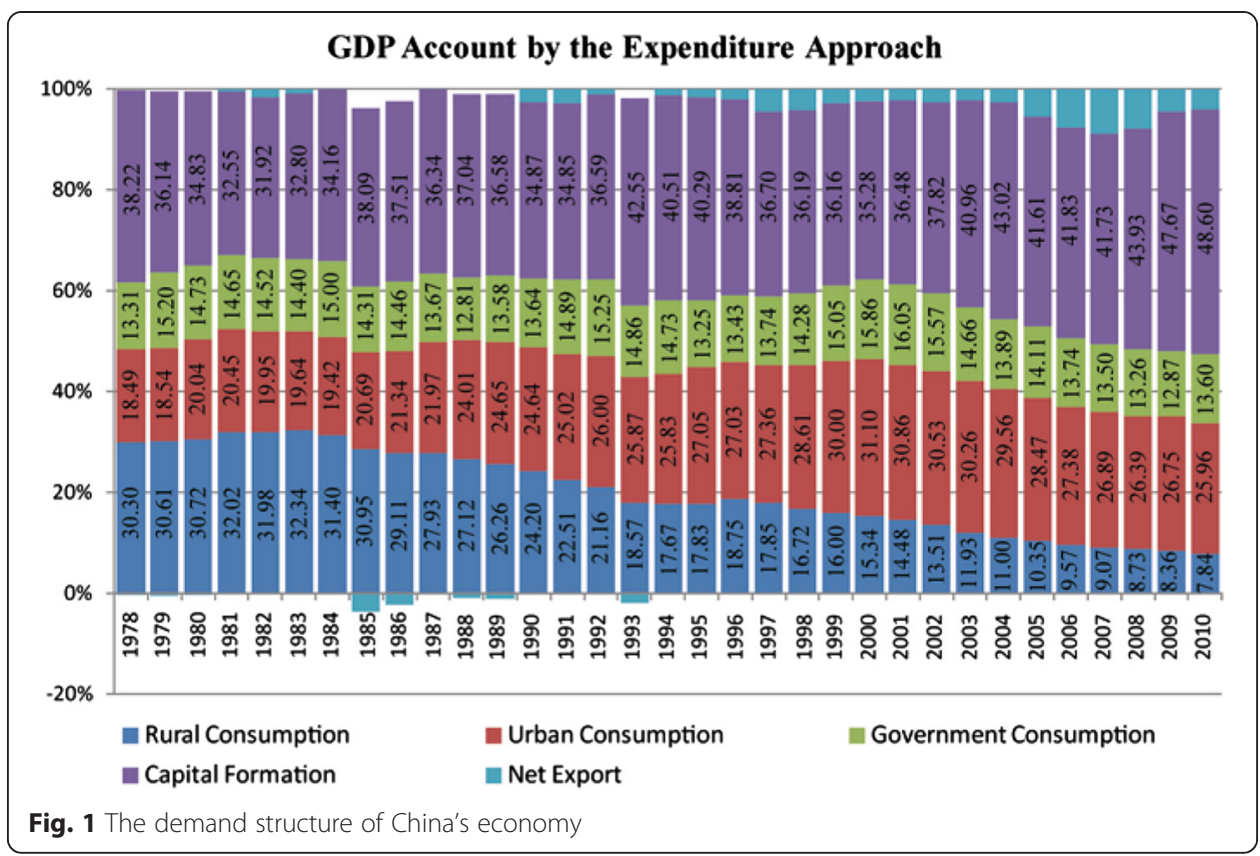

consumption habit falls behind income rise, resulting in higher savings. Finally, income inequality is believed to be another reason behind the high savings rate. Some argue that richer people have higher savings rates. Others argue that with more skewed income distribution, lower income people save more in order to catch up with the more affluent neighbors. All these arguments focus on the household sector as the driver of the increased savings rate. This cannot be the whole story, or even the most important story. In 2000, household disposable income was about $65 \%$ of GDP, and household savings rate was about $28 \%$. If the share of household disposable income in GDP had not changed from 2000 to 2010, as household consumption declined from $46.4 \%$ of GDP in 2000 to $33.8 \%$ in 2010, household savings rate would have to increase from 28 to $48 \%$, which is highly unlikely to have happened. Therefore, the decline in the share of household disposable income in GDP is almost certainly an important factor behind the increased savings rate. To understand the reasons for the increased savings rate, it is necessary to understand why household income share has declined.

The third question is what policies can help reduce savings rate and increase household consumption rate. These policies have to target the underlying factors behind our problem. Meanwhile, it is also necessary to consider other possible effects of these policies so that no new problems are created in the process of solving an old problem. This paper attempts to answer these three questions in turn.

\section{Is the savings rate too high?}

Savings can be used for domestic investment and overseas investment. Overseas investment is the part of GDP that is not consumed or invested domestically and is therefore equal to net export, or trade surplus. It is hard to imagine the share of trade surplus in GDP can maintain sustained growth for a large and fast-growing economy such as China. The reason is the Chinese economy grows faster than the world average, and therefore, for the share of trade surplus in GDP to grow in China, the share of trade 
deficit in GDP in the rest of the world taken as a whole will have to grow faster. For example, suppose the Chinese economy grows by $8 \%$ a year, but the average annual economic growth rate in the rest of the world is $5 \%$, then the share of trade deficit in GDP in the rest of the world taken as a whole will grow 3 percentage points faster than the share of trade surplus in GDP in China. This cannot be sustainable. In fact, China's share of trade surplus in GDP dropped from $8.8 \%$ in 2007 to below $4 \%$ in 2010, and it is still declining. Therefore, we cannot expect China's share of overseas investment in GDP to grow consistently. If that is the case, then high savings rate will have to mean high domestic investment rate.

China's investment rate increased from $35.3 \%$ in year 2000 to $48.6 \%$ in year 2010 . According to Penn World Table, only 12 countries in the world, Kiribati, Suriname, Cape Verde, Sao Tome and Principe, Marshall Islands, Qatar, Saudi Arabia, Lebanon, Botswana, Bahrain, Grenada, and Bahamas, had higher investment rates than China in 2009. In the same year, the average investment rate among 40 largest economies excluding China was $22.4 \%$, just half that of China.

These numbers tell us that China's investment rate has increased very rapidly in the last decade and its level is extraordinarily high among major economies. However, these numbers alone do not necessarily mean that China is investing too much as is explained in the introduction. It is necessary to examine other factors to make the judgment.

One indicator to consider is the rate of return to investment. The 2006 paper by Bai, Hsieh and Qian in Brookings Paper on Economic Activity estimates these rates by using the GDP account data of China. The capital stock is estimated by the perpetual inventory method. Capital accumulation is divided into two types, equipment on the one hand and buildings and structures on the other. Different price indices and depreciation rates are used for the two types of investment, with the depreciation rate derived from the average life time and the average residual value at the end of the life time of the investment. The share of capital income in GDP is computed from provincial capital shares since national capital share is only published with a lag of a few years. The after tax and after depreciation rates of returns to capital are illustrated in Fig. 2.

The figure shows a declining trend of the rates of return to capital. In 2010, the last year when the estimate is available, the rate of return was as low as $5.1 \%$. Note that this is the average rate of return to capital of the whole country. For firms with some monopoly power, the marginal rate of return to capital is lower than the average rate of return because the latter includes the monopoly profit, and therefore the average

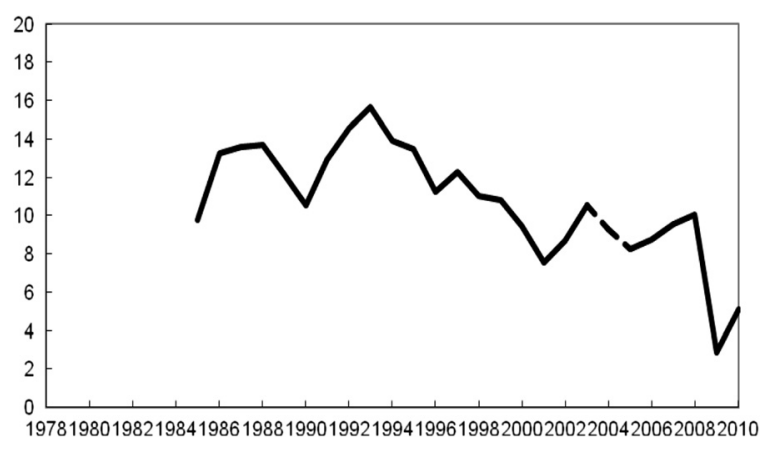

Fig. 2 After tax and after depreciation real rates of return to capital 
marginal rate of return to capital of the whole country is below $5.1 \%$. Furthermore, because the rate of return to capital varies across investment projects, there must be many projects with marginal rate of return even lower than $5.1 \%$. These results about the rates of return to capital suggest that one needs to be concerned about overinvestment, especially if the declining trend continues.

It has been argued once and again that China does not need to worry about overinvestment because it is still a relatively poor country and per capita capital stock is still much lower than that in advanced economies. This argument is flawed. Investment should go hand in hand with total factor productivity. It will take a long time for China to catch up with advanced economies in terms of total factor productivity, and therefore it should also take a long time for per capita capital stock in China to approach the advance level. When the pace of investment is too much faster than that of the improvement in total factor productivity, investment will generate a very low return, as is evidenced by our estimate of the rate of return to capital.

It has also been argued that high investment rate is indispensable for economic growth. However, the growth of output is not the ultimate objective; the growth in consumption is more important than the growth in output. Raising investment rate can increase output. However, if investment rate is too high, raising investment further will reduce consumption. According to the Solow growth model, the golden rule level of savings rate that maximizes consumption is equal to the capital income share. In China, the average share of capital income in all factor income between 1992 and 2007 was about $38.7 \%$ if we use the data from the 2007 version of the flow of funds table, and was about $43.7 \%$ if we use the GDP account data by the income approach. Both of these two numbers are much lower than the investment rate of $48.6 \%$. That is, China's investment rate is much higher than the golden rule level, suggesting that the investment rate is too high for maximizing consumption and so is the savings rate.

\section{Why is the savings rate so high?}

There is a lot of discussion about China's high savings rate. Much of the discussion is focused on household savings. The questions are how much household savings rate has increased and whether the rise in household savings rate alone can explain the rise in national savings rate.

According to the flow of funds table, household savings rate was $27.5 \%$ in 2000 and $38.1 \%$ in 2007 . This is indeed a very rapid rise. From the same data source, the share of household disposable income in GDP was $62.8 \%$ in 2000. Suppose this share had not changed, then the rise in household savings rate from 27.5 to $38.1 \%$ would imply a rise in national savings rate of 6.7 percentage points. However, in the same period, national savings rate actually rose by 13.3 percentage points. That is, the increase in household savings rate alone can only explain half of the rise in national savings rate.

Furthermore, there are reasons to believe that the flow of funds table overstates the increase in household savings rate and the decline in household consumption rate. One reason is that the flow of funds table understates the rise in government income. For example, for the period of 2000 to 2007, the flow of funds table reports an increase in the share of net production tax in GDP of 1.1 percentage points, but the Yearbook of Fiscal Affairs reports an increase of 3.5 percentage points. The other reason is that it understates the decline in the labor income share and therefore the increase in the 
share of corporate disposable income in GDP. According to the flow of funds table, the labor income share dropped by only 2.7 percentage points between 2000 and 2007, while GDP account data by the income approach imply a drop of 5.3 percentage points. Both of these biases lead to an understatement of the decline in the share of household disposable income in GDP and therefore an overstatement of the decline in household consumption rate.

To better understand how the change in household savings affects the change in national savings rate, we make adjustments to the flow of funds table by using more reliable sources of data and compute household savings rate and the share of household disposable income in GDP using the adjusted flow of funds table. We use data from the Yearbook of Fiscal Affairs to adjust government income and the GDP account data by the income approach to adjust the labor income share. Our first finding is that household savings rate did not increase nearly as much as the original flow of funds table indicates, as illustrated by Fig. 3. From 2000 to 2007, household savings rate increased from 26 to $32.2 \%$. This alone is certainly not enough to explain the 13.3 percentage point rise in national savings rate in this period.

Our second finding is that the share of household disposable income in GDP experienced a very sharp drop in this period, as illustrated by Fig. 4. From 2000 to 2007, the share dropped from 61.6 to $50.9 \%$. Meanwhile, both the shares of government disposable income and corporate disposable income in GDP rose, with the former rose by 7.6 percentage points. Furthermore, government savings rate increased from 11.4 to $47.1 \%$ in this period. As a result of these changes, the share of household savings in GDP increased by only 0.5 percentage point, a very small portion of the 13.3 percentage points rise in national savings rate in this period. However, the share of government savings in GDP increased by 9.8 percentage points, and the share of corporate savings to GDP increased by 3 percentage points, as illustrated by Fig. 5 . In short, the increase in household savings is only a very small part of the increase in national savings rate; and the increase in government savings is the most important part, followed by the increase in corporate savings. These changes are driven by two phenomena, one is the rapid decline in the share of household disposable income in GDP and the other is the dramatic increase in government savings rate. The second driver follows from the first because the rapid increase in government disposable income allows the government to invest more of it rather than consuming it.

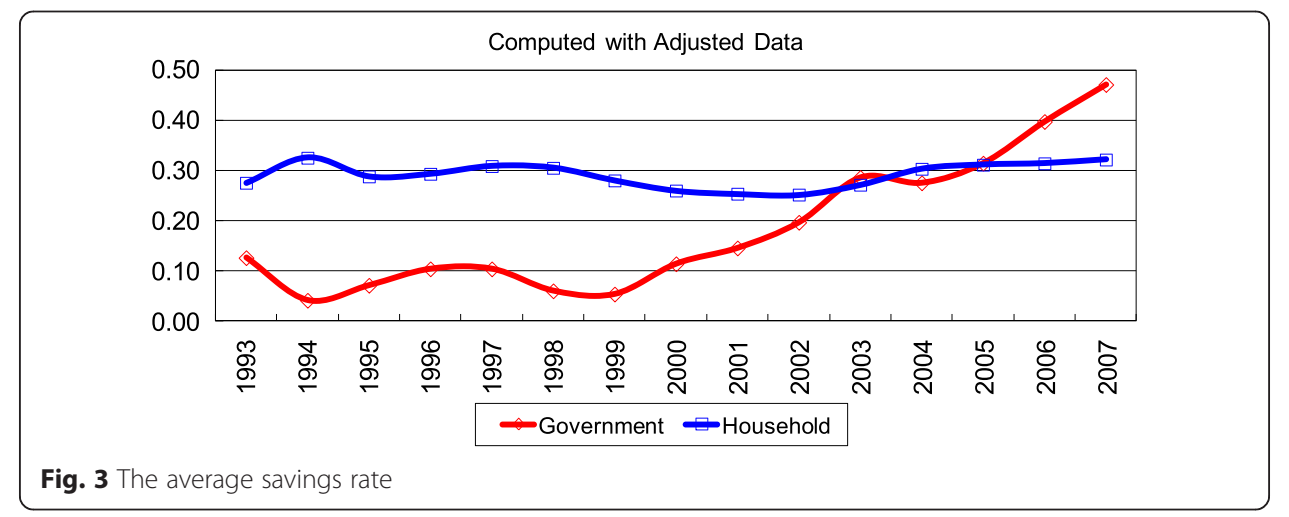




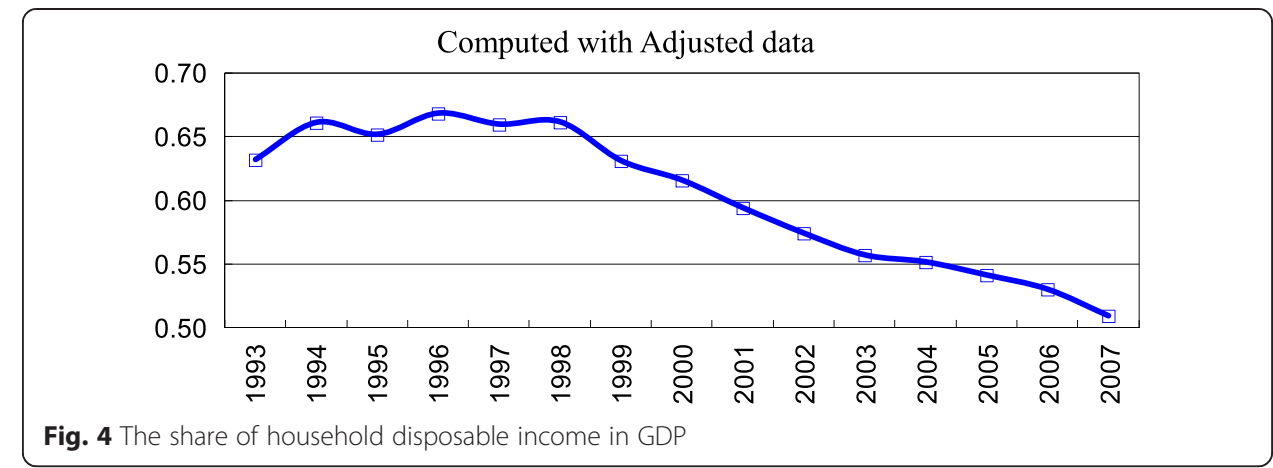

One may argue, a la Ricardian equivalence, that the distribution of income among households, corporations and the government should not affect national savings if government consumption does not change; when corporations and the government save more, households, as owners of corporations and tax payers, will benefit from these savings in the future and should save less now. This argument is particularly irrelevant in the context of China. Big corporations, often state owned, and the government do not invest efficiently, and as a result, households view the increase in corporate and government disposable income as permanently lost household income rather than household savings temporarily held by the corporations and the government. Distribution of income among households, corporations, and the government matters.

Household disposable income is affected by six factors: labor income, household capital income, household business operating surplus, income tax payment, net social security payment, and other transfers received by the household. From the adjusted flow of funds table, we find that the changes of these factors are all in the direction of reducing the share of household disposable income in GDP; that is, the shares in GDP of labor income, household capital income, household business operating surplus, and other transfers received by the household all declined, and the shares in GDP of individual income tax payment and net social security payment both increased. The most important factor is the decline of the labor income share.

Between 2000 and 2007, the labor income share declined from 48.7 to $43.5 \%$. The most important source of this change is the structural transformation from agriculture to industry and services. The labor share in agriculture is significantly higher than those

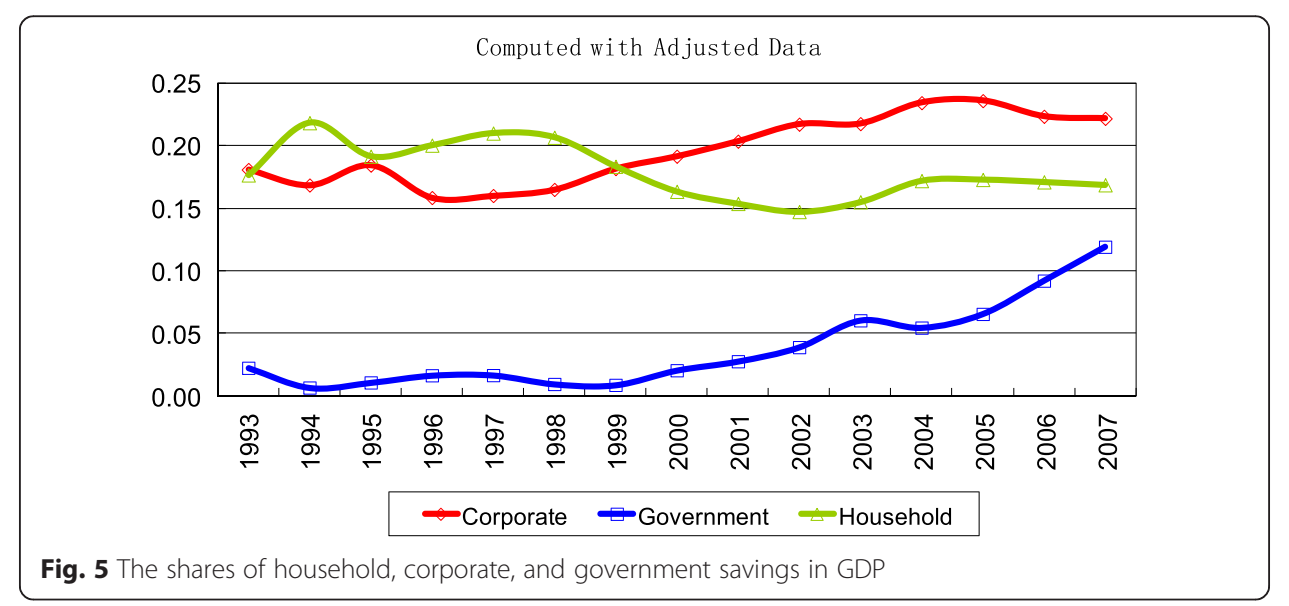


in industry and services. As the weight of agriculture declines, the aggregate labor share declines. The second most important source is the decline of labor share in industry. Using firm level data from industry, we find that the decline of labor share in industry can be mostly explained by the reform of the state-owned enterprises and the increase of monopoly power, with the former playing a much bigger role than the latter. Labor share tends to be higher in state-owned enterprises than in enterprises of other ownership types. With the reform, the share of state-owned enterprises in the economy has been declining, leading to the decline in aggregate labor share. Furthermore, within state-owned enterprises, labor share has declined as these enterprises shed more and more of their surplus labor in the process of the reform. As for the impact of monopoly power on labor share, if firms with monopoly power are compared with other firms, even though the former pay their employees more, their profits are even higher, and therefore their labor shares are lower.

An often mentioned reason for the decline in the labor income share is that wages rise very slowly due to the large pool of surplus labor in the rural area. This is not a real reason. If wages rise more slowly than productivity, employment will rise quickly. These two effects cancel each other and do not affect the labor income share if the elasticity of substitution between labor and capital is one. Using the firm level data in industry, we find that the elasticity is indeed not significantly different from one.

\section{Policy discussion}

Since labor income is the most important component of household income, in order to increase household income, one naturally thinks of measures to increase labor income. However, there is very limited scope for policies to make a significant difference here.

The most important source we found of the decline in the labor income share is the structural transformation from agriculture to industry and services. This is a necessary transformation for economic development. One certainly should not interfere with this process for the sake of increasing the labor income share. If anything, urbanization is one of the most important sources of productivity gain and it should be actively promoted.

The second most important factor behind the decline in the labor income share is the reform of state-owned enterprises. This has been another of the important sources of efficiency improvement and should be continued.

It is the third reason of the decline of the labor income share that should be the target of change. In addition to its effect on the labor income share, the increase in monopoly power damages not only efficiency but also fairness. However, the effect of reducing monopoly power on the labor income share is limited because monopoly power only explains about $10 \%$ of the change in the labor income share.

Another factor behind labor share is the development of the services sector. Because the labor income share in the services sector is higher than that in industry, its average value will rise if there is a structural transformation from industry to services. The recent government experiment of replacing the business tax which is levied on sales revenue with the value added tax in the services sector should be a significant boost to the services sector. Reducing the biases against the services sector in terms of land allocation and entry barriers should also have a positive effect. However, the effects of these measures on labor income are most likely to be slow. 
It is often proposed that the minimum wage should be raised in order to increase labor income. This measure has two opposing effects on labor income; it raises the wages of those who are employed but reduces employment growth. Our study based on firm level data in the manufacturing sector finds that these two effects almost exactly offset each other. Therefore, raising minimum wages does not increase labor income, but it reduces employment creation and economic growth.

Some of the rural policies have the effect of increasing rural income and reducing the incentive for rural to urban migration. It is hoped that such measures will push up urban wages and therefore increase labor income. However, these policies do not increase urban labor income even if they raise urban wages, because they reduce urban employment creation as we discussed earlier. They also reduce labor market efficiency by hindering the productivity gain from urbanization. It is possible to increase the household income of rural population without distorting the migration decision, if we allow migrant workers continue to receive benefits that are equivalent to the transfers embedded in the rural policies. Providing better education to the children of migrant workers is one example of such a benefit that has lasting effects on economic development and equity.

Since not much can be done to increase the labor income share, one needs to think about other channels to increase household disposable income. One such channel is household capital income. Among the most important household income-generating assets are bank deposits. However, households in China are shortchanged in this source of income because deposit interest rates are regulated by the central bank and they are below the equilibrium deposit interest rates. One piece of evidence to support this statement is that banks raised their deposit interest rates immediately after the central bank allowed them to in June, 2012. If the deposit interest rates are raised further, household capital income will increase further, both directly from bank deposits and indirectly through the upward pressure on the return to other assets. Furthermore, interest rate liberalization will play an important role in improving the efficiency of the financial sector. The government should take resolute measures to speed up the process of interest rate liberalization.

The government should also make it easier for households to invest in foreign assets so that they have a larger selection of assets to invest in. One measure that can achieve this goal is to allow foreign companies list their equity shares or issue bonds on stock exchanges in China. The government should also encourage the development of intermediaries to help Chinese households to invest in overseas securities.

Another channel to increase household disposable income is to reduce net social security payment or income tax payment. The statutory rates of social security payments are very high. The national guideline is as follows. For pension, employer payment is $20 \%$ of basic salary and the employee's is $8 \%$. For medical insurance, employer payment is $6 \%$ of basic salary and the employee's is $2 \%$. There are also unemployment insurance, injury insurance, and maternity insurance. All together, the total payment rate is about $40 \%$ of the basic salary. This rate is the 13th highest in the world.

The social security payment is subject to a ceiling and a floor. If the basic salary is above three times of the regional average salary, the part above is not subject to social security levy. However, if the basic salary is below $60 \%$ of the regional average, the payment is computed as if the basic salary was $60 \%$ of the regional average. These features 
imply that not only is social security payment a heavy burden on employees and their employers but also a regressive levy among people who participate in the program. The very high payment rates also discourage participation in the program. There is a strong case for reducing the payment rate.

If the social security benefits are cut by the same amount as the reduction of the payment, then household disposable income is not increased and it only redistributes income between the workers and the retired. To increase household disposable income, the government needs to find other sources of income for the social security program so that it can cut the payment rate without reducing the benefits. To prevent the social security program to become an unsustainable burden on public finance, the sources of income for the program should have limited scope. One good candidate is the dividend payment by state-owned enterprises. Currently, their dividend payments are mostly reinvested in the state sector. Because such investment is not subject to sufficient oversight, it is a source of the overinvestment problem we discussed earlier. If state-owned enterprises indeed need funds for worthy investment, they can always raise them from financial institutions or the capital markets, or in the case where the investment is not commercially profitable but is of public interest, they can ask the government for funding. Raising investment funds externally helps improve the governance of the enterprises. Furthermore, when there is much resentment against state-owned enterprises among the population, using their dividend payment to support the social security program can win popular support that is necessary for carrying out important reforms to the program, such as postponing the retirement age.

Compared to reducing social security payment rate, cutting individual income tax does not offer as many benefits. One reason is that cutting individual income tax does not help the large portion of the population who do not pay individual income tax anyway because their income is below the exemption threshold, while cutting social security payment rate helps low-income participants proportionately more.

\section{Conclusions}

China's investment rate has been increasing very fast since the beginning of the new century, and it is also very high compared to that in other major economies. This paper reports an estimate of the rate of return to capital and finds that it shows a steady trend of decline since the early 1990s. In 2010, the average after tax and after depreciation real rate of return was as low as $5.1 \%$. The paper argues that the investment rate is too high not only because of the low return but also because it is higher than the level that theoretically maximizes consumption. It is also argued that the investment rate is strongly tied to the savings rate.

By analyzing the flow of funds table and the GDP account data, this paper argues that the main reasons behind the rapidly increasing savings rate are the drastic change in the distribution of income among households, corporations, and the government, and the consequent increase in government savings rate. Further analysis indicates there are many reasons for the drastic decline in the share of household disposable income in GDP, with the drop in the labor income share as the most important one. The paper then reports that the structural transformation from agriculture to industry and services is the most important reason behind the decline in the labor income share. The analysis of firm level data in the manufacturing sector shows the reform of state-owned 
enterprises and the increase in monopoly power are two other reasons for the decline in the labor income share, with the former much more important than the latter.

The paper finally discusses policy implication of the findings. It argues that there is limited scope for policies to affect the labor income share. It proposes that reforms in the financial sector and the social security sector can play positive roles in increasing household disposable income and household consumption.

Competing interests

The author declares that he has no competing interests.

Author's information

Bai Chong-En is the Associate Dean of the School of Economics and Management, Tsinghua University. Professor Bai mainly researches and teaches Chinese Economy, Organizational Economics and Public Economics.

Acknowledgements

Thanks for the funding of the National Social Science Fund (10\&ZD007)

Received: 11 September 2012 Accepted: 11 October 2012

Published online: 08 December 2015

Submit your manuscript to a SpringerOpen ${ }^{\odot}$ journal and benefit from:

- Convenient online submission

- Rigorous peer review

- Immediate publication on acceptance

- Open access: articles freely available online

- High visibility within the field

- Retaining the copyright to your article

Submit your next manuscript at $>$ springeropen.com 